\title{
Development of Teacher Leadership Identity: A Multiple Case Study
}

Deborah L. Hanuscin. Ph.D

(C) 2017. This manuscript version is made available under the Elsevier user license http://www.elsevier.com/open-access/userlicense/1.0/ 


\section{Introduction}

Whereas principals and other administrators have been considered the primary (and often sole) 'leaders' in schools throughout most of the $20^{\text {th }}$ century, the concept and practice of 'teacher leadership' has gained increasing attention in recent years (Barth, 2001; Beachum \& Dentith, 2004; Hunzicker, 2012; Margolis \& Deuel, 2009; York-Barr \& Duke, 2004). The priority given to teacher leadership is reflected in the National Science Foundation's (NSF) Math and Science Partnership (MSP) program, which aims to "prepare highly qualified, experienced teachers to become exceptional Teacher Leaders" (NSF, 2010), and in a growing number of studies related specifically to science teacher leadership (e.g., Howe \& Stubbs, 2003; Pellicer \& Anderson, 2001; Wallace, Nesbit, \& Miller, 1999; Yow \& Lotter, 2014; Mentzer, Czerniak, \& Struble, 2014). Teacher leadership is being increasingly recognized as a catalyst for change and critical element to sustain curriculum reform efforts (Beachum \& Dentith, 2004; Hunzicker, 2012; Margolis \& Deuel, 2009; Larkin, Seforth, \& Lasky, 2008; York-Barr \& Duke, 2004). Researchers have investigated teacher leadership perspectives of practitioners and administrators (Angelle \& DeHart, 2011; Collay, 2006; Emira, 2010), characteristics and influences of teacher leadership courses and programs (Leonard, Petta, \& Porter, 2012; Ross et al., 2011; Taylor, Goeke, Klein, Onore, \& Geist, 2011), the impact of teacher leadership workshops and projects (Adams \& Gamage, 2008; Blackman, 2010; Frost, 2012), the influence and relation of school principals and teacher leadership (Carver, 2010; Ghamrawi, 2011), ways of leading within classrooms and for school improvement (Jacobson, 2011; Loeb, Elfers, \& Plecki, 2010), and, finally, factors that influence leadership growth and construction of leadership identities (Howe \& Stubbs, 2003; Lewthwaite, 2006; and Kenreich, 2002). Despite this growing body of research, there is a dearth of literature related to the process by which 
teachers become leaders, how professional development (PD) might be best designed to support that, and whether we can generalize the development of teacher leaders across career stages (Komives, Owen, Longerbeam, Mainella, \& Osteen, 2005; Lewthwaite, 2006; Martinez, 2004; Luft \& Hewson, 2014; Luft, Dubois, Kauffman, \& Plank, 2016; Wenner \& Campbell, 2016 York-Barr \& Duke, 2004). The focus of teacher leadership studies so far has been skewed towards experienced versus new teachers (Fairman \& MacKenzie, 2014; Lieberman \& Miller 20007; Lord, Cress, \& Miller, 2008; Taylor, Yates, Meyer, \& Kinsella, 2011; Weiner, 2011), and questions remain about pathways teachers at different career stages pursue in becoming teacher leaders, and whether those trajectories can be generalized for all teachers.

Our study is situated within this gap in literature, and contributes by documenting how teachers develop as leaders at different stages in their careers. We investigate teacher leadership development through the lens of identity, and through a comparative case study document how three teachers, at different stages of their career, evolved as leaders while participating in an NSF-funded MSP designed to support a cadre of teacher leaders implementing reform in their schools and districts. The overarching question guiding our study is: How do science teachers with various years of teaching experience develop as teacher leaders and through what process do these teachers build their teacher leadership identity?

\section{Conceptual framework}

We use two different, but complementary, ways of conceptualizing teacher leadership to guide the present study — that of leadership as practice and leadership as identity. We consider a 'teacher leader' to be one who not only engages in the practice of leadership, but who also identifies his/herself as a teacher leader. That is, teachers who engage in leadership activities but 
who do not view themselves as being 'leaders' (and vice versa) have not fully realized being a teacher leader. We elaborate on these two concepts of teacher leadership below.

\subsection{Teacher leadership as practice}

Traditional and formal conceptions of leadership (i.e., focused on the roles of principals, superintendents, head teachers, and department chairs) prevailed during the last century (Pounder, Ogawa, \& Adams, 1995; Stogdill, 1974; Wasley, 1991), with importance being given to positional and hierarchical conceptions of leadership (Darling-Hammond, Bullmaster, \& Cobb, 1995; Lieberman, 1988; Sharon \& Highsmith, 1986). More recently, the concept of teacher leadership has challenged this view (Katzenmeyer and Moller, 2009). Teacher leadership cam to be defined as:

... the process by which teachers, individually or collectively; influence their colleagues, principals, and other members of school communities to improve teaching and learning practices with the aim of increased student learning and achievement. Such leadership work involves three intentional development foci: individual development, collaboration or team development, and organizational development (York-Barr \& Duke, 2004, p 287). Defining teacher leadership as practice places the focus on the activities of teachers as they take on the role of 'leader'. In their review of the literature, York-Barr and Duke (2004) categorized teacher leadership practices across seven dimensions (See Table 1).

\section{Table 1}

Seven dimensions of teacher leadership practice

\section{Dimensions of Teacher Examples Leadership Practices}

Coordination and management Coordinating daily schedules and special event; Participating in administrative meetings and tasks; Monitoring improvement efforts; handling disturbances 


\begin{tabular}{ll}
$\begin{array}{l}\text { School or district curriculum } \\
\text { work }\end{array}$ & $\begin{array}{l}\text { Selecting and developing curriculum; Defining outcomes } \\
\text { and standards. }\end{array}$ \\
\hline PD of colleagues & $\begin{array}{l}\text { Mentoring other teachers; Engaging in peer coaching; } \\
\text { Leading workshops; Modeling, encouraging professional } \\
\text { growth. }\end{array}$ \\
\hline $\begin{array}{l}\text { Participation in school change } \\
\text { and improvement initiatives }\end{array}$ & $\begin{array}{l}\text { Taking part in school-wide decisions; Working with peers } \\
\text { for school change; Facilitating communities of teacher } \\
\text { learning through organization-wide process; Participating in } \\
\text { research, notably action research; Confronting barriers and } \\
\text { challenging the status quo in the school's culture and } \\
\text { structures. }\end{array}$ \\
$\begin{array}{ll}\text { Parent and community } \\
\text { involvement }\end{array}$ & $\begin{array}{l}\text { Becoming involved with parents; Encouraging parent } \\
\text { participation; Creating partnerships with community } \\
\text { business; Working with the community and community } \\
\text { organizations. }\end{array}$ \\
\hline $\begin{array}{l}\text { Contributions to the profession } \\
\text { of teachers }\end{array}$ & $\begin{array}{l}\text { Participating in professional organizations; Becoming } \\
\text { politically involved. }\end{array}$ \\
\hline Pre-service teacher education & $\begin{array}{l}\text { Building partnerships with colleges and universities to } \\
\text { prepare future teachers. }\end{array}$ \\
\hline &
\end{tabular}

Note. Seven dimensions of teacher leadership practice. Adapted from "What do We Know about Teacher Leadership? Findings from Two Decades of Scholarship," by J. York-Barr and K. Duke, 2004, Review of educational research, 74(3), p.266

Through engaging in leadership practices, teacher leaders a) facilitate communities of learning;

b) nurture a culture of success; c) strive for pedagogical excellence; d) confront barriers in school culture and structure; e) convey their convictions; and f) translate ideas into sustainable systems of action, (Crowther, Kaagan, Ferguson, \& Hann, 2002).

\subsection{Teacher leadership as identity}

While the work of teacher leaders can be examined through their practices, as above, the process of becoming a teacher leader can be viewed through the theoretical lens of identity. Identity is based on two core constructs - social roles and role identities (Krause, 2004). 
According to Krause (2004), social roles played by an individual indicate her/his position in a group, and identities refer an individual's self-image and way it is presented to others. This is echoed by Gee (2000), who emphasized that the meaning of identity also encompasses the perception of others and the way one is recognized in any given context. Thus, an individual progresses towards complex ways of 'being' a leader through various personal experiences, new roles, social interactions, and feedback from others (Renn \& Bilodeau, 2005).

According to current research, several factors play a key role in identity formation of leaders, such as leadership vision, leadership roles and practices, and the importance of feedback recognition, and reflection. A teacher's personal outlook or vision with regards to teacher leadership affects their perception of self-leadership and contributes to the ongoing process of identity formation (Komives et al., 2005). This personal vision also shapes their ideas of various leadership practices and roles leaders play. Gonzales and Lambert (2001), particularly with regards to teachers, pointed out that taking on new leadership roles brought forth a sense of being a leader in them. Newer roles made them confident and they understood their ability to confront with various issues. Furthermore, taking on new roles (for example roles formal/ authoritative in nature) brought more responsibility and positive feedback from others. Feedback and recognition were also identified as contributors to the development of teacher leadership identity by Gonzales and Lambert (2001). Positive experiences in which teachers' leadership capabilities were acknowledged, along with feedback from colleagues, facilitated the emergence of confidence and through this their sense of self was redefined.

This self-consciousness of personal growth has also been recognized as a crucial factor in leadership identity development. Komives et al. (2005) emphasized reflection prompts an individual to be self-critical on their leadership activities and leadership conceptions. These 
reflections can be both personal or take place with colleagues. Luehmann (2007) explored teacher professional identity development as related to educational reform, and recommended that reform-minded teachers should help novice teachers find safe spaces where they can develop new identities. In these safe spaces, they can be recognized by themselves and others through continuous and supported reflection.

\section{Context of the Study}

The context for this study was Science Teachers as Leaders ${ }^{1}$, an NSF-supported program focused on "meeting national needs for teacher leaders/ master teachers who have deep knowledge of disciplinary content for teaching and are fully prepared to be school- or districtbased intellectual leaders in mathematics or the sciences" (NSF, 2010). Participating teachers $(\mathrm{N}=86)$ committed to three years, or a total of 300 hours of PD that included extended face to face (summer academies) and online (academic year) interactions focused on content, pedagogy, curriculum, and leadership necessary to serve as leaders in the implementation of a freshman physics course in their schools and districts.

\subsection{Explicit focus on teacher leadership.}

This PD supported teachers in shaping their definition of teacher leadership, exploring possible avenues of teacher leadership - both formal and informal, and strategizing ways to overcome barriers and challenges to teacher leadership. Teachers created and implemented individual leadership action plans each year of the program, reflecting on their progress throughout. The leadership focus of this program was designed not only to enhance teachers' individual leadership skills and capacity, that is - their practice as teacher leaders, but also to support the development of teachers' identity as teacher leaders (Authors, 2016).

\subsection{Common vision of 'teacher leadership.'}

${ }^{1}$ pseudonym 
PD sessions were designed to promote a common vision of teacher leadership and address disconnects between the activities in which teachers participated and those they considered to be 'leadership' (Authors, 2012). Teachers were exposed to diverse conceptions of leadership through the literature and through firsthand accounts (e.g., blogs) of teacher leaders. Throughout the program, teachers discussed their evolving definitions of leadership, their leadership experiences, characteristics of an effective leader, and how teacher leadership could be part of, rather than in addition to, their day to day activities as teachers.

\subsection{Opportunities to lead.}

Teachers were assisted in identifying opportunities to lead by considering the seven dimensions of teacher leadership practices (York-Barr and Duke, 2004), examining their current roles and responsibilities, and identifying formal and informal roles available to them as leaders. Teachers customized a leadership action plan (Authors, 2011) to address a pressing need related to their school's implementation of freshman physics. Moreover, group discussions informed teachers of leadership opportunities their colleagues were pursuing, and how these might translate into their own contexts.

\subsection{Feedback and recognition.}

Throughout the program, teachers received continuous feedback and recognition for their leadership activities. For example, during summer academy teachers received feedback on the design of their leadership action plans from peers and staff, which they also shared with their administrators. During the academic year, teachers blogged about their concerns, challenges, and successes (Authors, 2014). This forum offered teachers access to suggestions and strategies to overcome barriers they faced in becoming teacher leaders, as well as expressions of support and appreciation for their leadership efforts. Academic year follow-up sessions provided further 
opportunities for teachers to report their leadership activities, receive feedback, and recognize the efforts of their peers.

\subsection{Reflection on growth as teacher leaders.}

The PD also provided structured and guided opportunities for reflection. Teachers submitted a mid-year and final progress report in which they self-evaluated their leadership action plans. Blogs, in particular, became important reflection tools and formed a chronological diary of their thoughts and growth as teacher leaders over the course of the year.

\subsection{Sustained support for teacher leadership development.}

Teacher leadership development, viewed through an identity lens, is a continuous process and thus sustained support is necessary. By continuing access to the program's online environment beyond the PD program itself, teachers were able to access information, share resources, and reconnect with others. In addition, partnering with our state's science teachers' association to create a leadership strand within the annual conference provided a means for sustaining relationships and continuing professional development.

\section{Methodology}

\subsection{Design of study.}

This study used a multiple case study approach (Yin, 2003) as three individual cases were examined to elucidate the phenomenon of teacher leadership development. Three teachers, different from each other with regard to years of teaching experience, were purposefully chosen from among the broader pool of participants to illustrate the phenomenon of teacher leadership development at different stages in teachers' careers. These teachers, Brandon, Elisa, and Martin, had one, 13, and 17 years of teaching experiences respectively when they joined this program. 
Though Elisa and Martin were close in their years of classroom experience, teaching was a second career for Elisa.

\subsection{Data sources.}

Multiple data sources were used in this study to get a comprehensive understanding of the phenomena (Bogdan \& Biklen, 1998), to allow cross validity checks (Patton, 2001), and enable triangulation of findings (Howe \& Stubbs, 2001). Numbers are used in this article, where appropriate, to indicate the year (e.g., Y1) of the PD in which data were gathered. Data sources are described in Table 2.

Table 2

Data Sources.

\begin{tabular}{ll}
\hline Data Source & Description \\
\hline Application (AI) & $\begin{array}{l}\text { Demographic and other professional information; Prior leadership experiences; Reasons for } \\
\text { joining this PD / leadership development program }\end{array}$ \\
$\begin{array}{l}\text { Discussion Forums } \\
\text { (DF) }\end{array}$ & $\begin{array}{l}\text { Teachers also took part in the online discussions in follow-up to face-to-face PD sessions. } \\
\text { The discussions in this forum were grouped under different topical headings related to } \\
\text { readings about teacher leadership (What is leadership? Challenges for Leaders, Taking } \\
\text { Action Through Leadership, Your Growth as a Leader, The Importance of Reflection, and } \\
\text { How to Sustain Reform). }\end{array}$
\end{tabular}

Action Plans (AP) A year-long individualized action plan (completed each of the 3 years) to achieve a goal related to the successful implementation of freshman physics; Crucial because action plans depicted the focus of their leadership activities and the roles and responsibilities of teachers as leaders.

Midyear (MR) and Final year (FR) progress reports

These reports were used to gauge and assess each teacher's progress in the context of the implementation of their action plans. The mid-year progress report detailed the current standing of each teacher about the implementation of his or her leadership action plan. In contrast, the final year report was intended to gauge the development of the teachers as leaders on the backdrop of their completion of leadership action plan.

Blogs (BL) During the school year, each teacher posted a monthly blog and responded to at least another one other blog posting. In their blogs, teachers reflected on their leadership practices and discussed barriers/facilitators in their leadership development and implementation of their action plans. Blogging helped geographically dispersed teachers connect virtually and discuss day-to-day school problems, share success stories, gain support from one another as they explored their personal pathways of leadership.

Interviews (INT)

Two phases of individual in-depth semi-structured interviews were conducted with each of the case participants. These interviews focused on ways to understand their overall growth as teacher leaders in general and leadership identity in particular. 
Life store exercise (LSE)
Life story is "the story a person chooses to tell about the life s/he has lived, told as completely and honestly as possible, what the person remembers of it and what s/he wants others to know of it" (Atkinson, 1998, p. 125). Life story prompts (appendix A) were provided to the case participants.

\subsection{Data analysis.}

A two-step qualitative data analysis procedure was followed. For our first round of deductive analysis, we used York-Barr and Duke's (2004) dimensions of teacher leadership practices (Table 1) as an analytical lens to investigate the leadership activities of participants. We coded all data sources based on these seven dimensions, while remaining open to additional dimensions not captured in York-Barr and Duke's list. We summarized these codes for each participant across all data sources to analyze changes in leadership activities over time. These activities were matched across different time frames related to various data sources - prior to joining the PD, during first/second/ and third year of the PD, and interview transcriptions and life story narratives conducted during the final year of participants' involvement in the PD. In these data sources, among other things, teachers spoke about their present, past and future plans related to leadership activities.

Whereas the previous phase used deductive analysis, the second round of thematic analysis employed inductive (open) coding. Only those segments of the data identified as 'leadership practices' in the previous phase were considered at this point in the research and the unit of analysis was a sentence/ group of sentences that informed a single meaning or message. A total of 514 codes were generated in this process. Similar codes were identified and grouped together in relation to particular themes. This process resulted in 82 categories of codes that could be grouped in five different domains; these reflected themes about: teachers' views of leadership (41); teachers' identities as leaders (28); teachers' leadership practices (7); the 
benefits of the PD program in influencing their leadership identities (3); and critical shifts in teachers' views, identities and actions (3). The following table illustrates how individual codes were assigned categories then grouped in a domain.

\section{Table 3}

Example of grouping of similar codes.

\begin{tabular}{|c|c|c|}
\hline Domain & $\begin{array}{l}\text { Example Themes } \\
\text { (Categories) }\end{array}$ & Example Codes \\
\hline \multirow{3}{*}{ Leadership views } & $\begin{array}{l}\text { Leadership practices } \\
\text { vary in scale }\end{array}$ & $\begin{array}{l}\text { Small-scale leaders work with very few people. } \\
\text { Small-scale leadership does not have a set hierarchy. } \\
\text { Small-scale leadership is easier and more informal } \\
\text { because members know each other. } \\
\text { Big scale leaders lead at the school level. } \\
\text { Large-scale leaders have to prove themselves at the } \\
\text { beginning. }\end{array}$ \\
\hline & Leaders are visionary & $\begin{array}{l}\text { Leaders are visionary and know where their group is } \\
\text { going. } \\
\text { Leaders need to have vision. } \\
\text { Leaders need to be visionary and cognizant about } \\
\text { 'where' their group is going and 'how' to reach there. }\end{array}$ \\
\hline & $\begin{array}{c}\text { Leaders are group } \\
\text { oriented and } \\
\text { democratic in nature }\end{array}$ & $\begin{array}{l}\text { Leaders work towards consensus. } \\
\text { Leaders bring groups together for a common good. } \\
\text { Leaders should also try to consider others' views } \\
\text { while determining a vision. } \\
\text { Leaders should make decisions transparently in } \\
\text { general except some special situations. }\end{array}$ \\
\hline
\end{tabular}

Participants' actions within the virtual community (blog posts and responses to peers) were also analyzed to characterize teachers' leadership practices and engagement in identity work over time, and to enable the triangulation of themes emerging from other data sources. Table 4 provides an example of one of the participant's actions in the virtual community.

Table 4

Summary table of Elisa's comments to peers' blog posts

\begin{tabular}{lcccc}
\hline Actions through blog comments & Elisa (Year 1) & Elisa (Year 2) & Elisa (Year 3) \\
\hline Asking for clarification/further details & x x x x x x x x x & x x x x x x x x x x x x x x x x & x x x x \\
\hline Acknowledging other's idea/ perspective & x x & x x x x x x x x x x x & x x \\
\hline
\end{tabular}




\begin{tabular}{|c|c|c|c|}
\hline Identifying problems/challenges & X X X X X X X X & 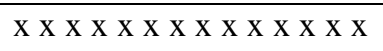 & \\
\hline Offering assistance/advice/suggestions & $\mathrm{x} \times \mathrm{x} \times \mathrm{x} \times$ & $\mathrm{x} \times \mathrm{x} \times \mathrm{x} \times \mathrm{x} \times$ & $\mathrm{x} \times \mathrm{x}$ \\
\hline Relating & X X X X X X X X & $\mathrm{X} \times \mathrm{X} \times \mathrm{x} \times \mathrm{X}$ & $\mathrm{XX}$ \\
\hline Expressing appreciation & X X X X X X X X & $\mathrm{X} \times \mathrm{XXX}$ & $\mathrm{x}$ \\
\hline Encouraging & $\mathrm{X} \mathrm{X}$ & X X X X X X & $\mathrm{XXX}$ \\
\hline Asking for advice/input & X X X X X X & $\mathrm{X}$ & $\mathrm{X}$ \\
\hline Describing strategies/plans & $\mathrm{x}$ & $\mathrm{x} \mathrm{X}$ & $\mathrm{x} \times \mathrm{x}$ \\
\hline Reflecting & $\mathrm{XXX}$ & & $\mathrm{XX}$ \\
\hline Asking rhetorical question & $\mathrm{XXX}$ & & $\mathrm{x}$ \\
\hline Sharing activity/ resources & $\mathrm{XX}$ & $\mathrm{x}$ & \\
\hline Accepting advice & $\mathrm{XX}$ & & \\
\hline $\begin{array}{l}\text { Adopting/Adapting any strategy/idea/ } \\
\text { activity }\end{array}$ & $\mathrm{X} \mathrm{X}$ & & \\
\hline $\begin{array}{l}\text { Advocating a common vision of effective } \\
\text { teaching }\end{array}$ & $\mathrm{x} \mathrm{X}$ & & \\
\hline Asking for resources & $\mathrm{x}$ & & \\
\hline Drawing on PD & & $\mathrm{X}$ & \\
\hline
\end{tabular}

Finally, we assembled all the data analyses to create case profiles, gathering all the coded data, corresponding categories, and domains separately for each participant. We then conducted a cross case analysis to examine the similarities and differences within each of the domains of all the participants. We present these cases and analysis in the sections that follow.

\section{Results and Discussion}

\subsection{Case 1 - Brandon}

Brandon (pseudonym), a white male in his mid-forties, was in his first year of teaching when he joined the PD program to get "a better understanding of physics through discussions, collaboration, and training with fellow science instructors" (AI). After working 14 years in pest control and a few years in real estate, he decided to become a teacher, and is provisionally 
certified. He teaches anatomy/physiology, chemistry, physical science, applied science and biology for grades nine through twelve in a rural school district.

\subsubsection{Leadership views}

According To Brandon, a leader should be charismatic, group oriented, collegial, reflective, and open to feedback. He initially believed that leadership was achieved through holding a formal position, having experience, or initiating change 'top down' and thought "leaders came with a title or a position of authority" and were the ones who "had been in the organization longer" (DF Y1). He believed that any type of reform, big or small, was orchestrated by men/ women of position. However, after participating in the program, he came to realize that “...it's not a title; and not that position creates a leader" (INT1) and ultimately believed that "leadership can and does come from anywhere within an organization" (FR Y2).

\subsubsection{Leadership practices}

Brandon's leadership practices, before, during, and after the PD program cut across several leadership dimensions identified by York-Barr and Duke (2004). Prior joining this program, Brandon participated in leadership activities related to school change/ improvement and contributing to the profession. During his first year, Brandon focused on promoting modeling pedagogy and whiteboarding. In addition, Brandon hosted a visit by a school science equipment company representative for demonstration, and coordinated a classroom observation schedule with another middle school science teacher. By the end of year 3, he expanded his leadership practice to include school/district curriculum work and parent/community involvement. Brandon took initiative in implementing teaching strategies to promote scientific inquiry and the Next Generation Science Standards (BL Y3). Teaming up with another colleague, he was involved in training staff and educating parents and community members about the benefits of inquiry-based instruction. This represented a shift in the scope of his 
leadership from within his class/school to leadership activities outside the classroom/school boundary.

Table 5.

Brandon's leadership practices

\section{Dimensions of Practice}

\begin{tabular}{|c|c|c|c|c|c|c|}
\hline $\begin{array}{l}\text { Coordination, } \\
\text { management }\end{array}$ & $\begin{array}{l}\text { School/District } \\
\text { Curriculum } \\
\text { Work }\end{array}$ & $\begin{array}{l}\text { PD of } \\
\text { colleagues }\end{array}$ & $\begin{array}{l}\text { Participation } \\
\text { in school } \\
\text { change/ } \\
\text { improvement }\end{array}$ & $\begin{array}{l}\text { Parent and } \\
\text { community } \\
\text { involvement }\end{array}$ & $\begin{array}{l}\text { Contributions } \\
\text { to the } \\
\text { profession }\end{array}$ & $\begin{array}{l}\text { Pre } \\
\text { service } \\
\text { teacher } \\
\text { education }\end{array}$ \\
\hline
\end{tabular}

Time

\begin{tabular}{llllll}
\hline $\begin{array}{l}\text { Prior } \\
\text { experiences }\end{array}$ & & & $\mathrm{X}$ & $\mathrm{X}$ \\
\hline Year 1 & $\mathrm{X}$ & $\mathrm{X}$ & $\mathrm{X}$ & $\mathrm{X}$ \\
\hline Year 2 & $\mathrm{X}$ & $\mathrm{X}$ & $\mathrm{X}$ & \\
\hline Year 3 & & $\mathrm{X}$ & $\mathrm{X}$ & & $\mathrm{X}$ \\
\hline Post Year 3 & $\mathrm{X}$ & $\mathrm{X}$ & $\mathrm{X}$ & $\mathrm{X}$ & $\mathrm{X}$ \\
\hline
\end{tabular}

\subsubsection{Identity as a teacher leader}

Brandon did not see himself as a 'teacher leader' when he joined this program, but eventually his self-perception changed. Although confident about his prior business leadership experiences, Brandon was not self-confident as a teacher leader. However, by the end of the first year, he referred to himself as a leader-in-development. "I am not one to just sit back... I know I still have a long way to go to reach my full potential as a leader however; I am addressing this..." (FR Y1). By the second year, he viewed himself as a leader in the form of a 'resource person' (FR Y2). Impressed by his growing self-confidence and leadership, the administration also encouraged him to take lead outside school by getting community members involved with the school (BL Y3). These helped in improving his self-perception and by the third year he had become confident of his teacher leadership abilities. His self-perception of teacher leadership 
was reinforced by school administrators, who recognized his skills and gave him the responsibility to lead school science department activities. Feedback from his colleagues also made him realize that he had "good ideas" and could be a credible source of information whenever "they are introducing something new" (FR Y2).

Presently, Brandon sees himself as a teacher leader, but insists, "I just try to lead by example" (INT 1). There were two visible shifts that resulted in his teacher leadership identity development. The first turning point occurred when he realized that his contribution as leader could be built upon his life experiences, irrespective of the fact that he was a first year teacher, and that he could bring others on board with his schools new intiative. As he explained,

... one thing I have really tried to focus is on bringing others with me as I move forward ... and I think that this program helps me do that. [It] helps me see that being a business owner you have one thing in mind and that's profit and ... you bring up a few [people] with you but you don't bring up a lot. Whereas this program has helped me realize that the more you bring with you the more impact you are going to have...so we have to bring as many teachers with us as we can... and then all the students will come forward [improve their learning] (INT 2)

The second shift, which was more gradual, helped him to transition from being a business leader to an academic leader. According to Brandon, the PD helped him become credible in the eyes of others, and develop new leadership skills that were applicable in his school context.

\subsection{Case 2 - Elisa}

Elisa (pseudonym), a white female in her fifties, was in her 13th year of teaching when she joined the PD program. Before starting her career in academia, Elisa held the rank of Captain in the U.S. Army. However, she left this field because she felt she lacked the confidence needed to lead veterans whom she felt had much more experience than her within their duties.

\subsubsection{Leadership views.}


Elisa initially believed that leadership was always associated with taking charge, formal positions, and numbers of years of service. Having participated in the PD program, Elisa later expressed that everyone has the potential to lead through formal or informal means, and that leadership can vary in scale and scope - 'big' and 'small.' According to Elisa, 'small leadership' is easier, informal, more collegial, less hierarchical, and deals with a small group such as at the department level; in contrast, 'big leadership' is more formal, hierarchical, and deals with more people who are unknown to each other as in a district level. Thus, big or small, leadership entails dealing with groups of people and with regards to that an ideal leader, according to her, is a person who leads a group to a common goal by considering others' views, negotiating differences, and helping in reaching consensus. She also feels a leader should be patient, persistent, and able to take initiative. Elisa viewed becoming a leader as a complete and irreversible transformation, and that “...once you have been a leader, you will probably not go to the background completely" (INT 1).

\subsubsection{Leadership Practices.}

Elisa had participated in different dimensions of leadership practice prior to the program, and took on multiple projects during her first year; she facilitated curriculum planning, mentored teachers, served as a school intervention team member, and presented in a conference respectively. In year two she began to do activities related to 'parent and community involvement' as she organized a science night to help parents and community members understand science teaching in school and to get them involved with their child's learning. For all the three years, Elisa consistently engaged in leadership activities such as coordinating a science outreach program for elementary kids, leading for whole-school curriculum integration project, and co-teaching with colleagues to improve questioning skills and demonstrating how to use whiteboards in class. Besides these she was elected to the board of directors of the state 
science teachers association, and also served as a department chair. As show in Table 6, Elisa's activities cut across six of the seven dimensions of leadership practice.

\section{Table 6.}

Elisa's leadership practices

\begin{tabular}{|c|c|c|c|c|c|c|c|}
\hline \multirow[b]{2}{*}{ Time } & \multicolumn{7}{|c|}{ Dimensions of Practice } \\
\hline & $\begin{array}{l}\text { Coordination, } \\
\text { management }\end{array}$ & $\begin{array}{l}\text { School/District } \\
\text { Curriculum } \\
\text { Work }\end{array}$ & $\begin{array}{l}\text { PD of } \\
\text { colleagues }\end{array}$ & $\begin{array}{l}\text { Participation } \\
\text { in school } \\
\text { change/ } \\
\text { improvement }\end{array}$ & $\begin{array}{l}\text { Parent and } \\
\text { community } \\
\text { involvement }\end{array}$ & $\begin{array}{l}\text { Contributions } \\
\text { to the } \\
\text { profession }\end{array}$ & $\begin{array}{l}\text { Preservice } \\
\text { teacher } \\
\text { education }\end{array}$ \\
\hline $\begin{array}{l}\text { Prior } \\
\text { experiences }\end{array}$ & & $X$ & $X$ & $\mathrm{X}$ & & $\mathrm{X}$ & \\
\hline Year 1 & $\mathrm{X}$ & $X$ & $X$ & X & & $\mathrm{X}$ & \\
\hline Year 2 & $\mathrm{X}$ & $\mathrm{X}$ & $\mathrm{X}$ & $\mathrm{X}$ & $\mathrm{X}$ & $\mathrm{X}$ & \\
\hline Year 3 & & $\mathrm{X}$ & $X$ & & & & \\
\hline Post Year 3 & $\mathrm{X}$ & $\mathrm{X}$ & $\mathrm{X}$ & & $\mathrm{X}$ & $\mathrm{X}$ & \\
\hline
\end{tabular}

\subsubsection{Identity as a teacher leader}

Elisa had never perceived herself as a leader when she joined the program, though her activities were consistent with the practice of teacher-leaders and she had served in a formal leadership role as a captain in army. Indeed, inconsistencies between her ideas about leadership and her discomfort with the authoritarian style of leadership of the military led her to change careers. Though she eagerly took on leadership activities, her confidence as a teacher leader did not come quickly. She used her students' achievement as the grounds for evaluating whether or not she was a 'leader'. As she worked toward "the improvement of rigor in [the] classroom" in year 2 of the program, she saw improvements in her students' learning and started perceiving herself as teacher leader. That same year, she successfully ran for the Board of Directors of the state science teachers' association. 
Through the program, Elisa was able to reconcile her identity as a leader with her views of teacher leadership. As she explained, "I see myself as a more capable person and I think that's both in being a teacher and being a colleague of a group of teachers and also a leader of a group of teachers" (INT 1). This identity was also recognized by her colleagues, school administrators, and community members, who saw her as an "innovator" (INT 2). She took the lead and started new programs such as science night, science crew outreach program where she lead high school students to do science outreach for elementary kids, and a recycling program where she took the lead to set up a steady paper recycling that ultimately helped the school and the community.

Elisa recognizes her growth in aspects of leadership such as having a voice, but also being open to new ideas, and has also developed her communication skills and mentoring ability, which she commented, "I would not have developed without [this program]" (INT 2). The program helped her realize that "you can actually get things started yourself" (INT 1), and she identified running for position with the state science teachers' association as a turning point in her leadership identity development.

\subsection{Case 3: Martin}

Martin (pseudonym), a white male in his forties, was in his $17^{\text {th }}$ year of teaching when he joined the PD program. He teaches earth science and physical science in a 9th grade center, where he is also the football coach. As the science department head, he works with five other science teachers in his building.

\subsubsection{Leadership views.}

Martin initially believed leadership to be hierarchical, requiring formal positions, and as such did not consider teachers to be leaders. For example, he viewed business executives, sports coaches, and educational administrators to be leaders. His leadership views widened as he went through this PD program, as he realized that "leadership does not reside in any title or position. It 
is the work that a person does being in that position counts" (INT 1). According to him, a leader is one who works together with others towards a common goal. With teacher leadership in particular, the common goal or end product of any leadership activity should be directed to students' learning success. A teacher leader should also take initiative versus always depending on the administration for directions. S/he should reflect upon leadership opportunities and use them for leadership growth. Martín stated that leaders should “...be able to think outside the box and not always just do things as they always had been done or not be afraid to take risks"(INT 1).

\subsubsection{Leadership practices.}

Martin's leadership practices, unlike Brandon's and Elisa's, were spread across all the seven dimensions of leadership practices given by York-Barr and Duke (2004). Martin had conducted training programs for his colleagues before joining this PD program that fell under the dimension of 'PD of colleagues.' Quantitatively, in year one his activities were spread over all the six dimensions of leadership practice, which was a great leap from his prior experiences. In year two it narrowed down to only five dimensions of leadership practice. He continued to share resources, successful teaching strategies, and his reflection along with his colleagues. Moreover, he gave his classroom a virtual platform by creating a classroom blog and twitter account as a way to be connected with the parents of the students. During the third year and after, Martin directed his effort toward sustaining the freshman physics program in his school, mentoring preservice teachers, and leading outside the school, serving as part of the district cadre planning committee and also on the district wide assessment for learning leadership team.

\section{Table 7.}

Martin's leadership practices

\section{Dimensions of Practice}

\begin{tabular}{|c|c|c|c|c|c|c|}
\hline $\begin{array}{l}\text { Coordination, } \\
\text { management }\end{array}$ & $\begin{array}{l}\text { School/District } \\
\text { Curriculum Work }\end{array}$ & $\begin{array}{l}\text { PD of } \\
\text { colleagues }\end{array}$ & $\begin{array}{l}\text { Participation in } \\
\text { school change/ } \\
\text { improvement }\end{array}$ & $\begin{array}{l}\text { Parent and } \\
\text { community } \\
\text { involvement }\end{array}$ & $\begin{array}{l}\text { Contributions to } \\
\text { the profession }\end{array}$ & $\begin{array}{l}\text { Pre service } \\
\text { teacher } \\
\text { education }\end{array}$ \\
\hline
\end{tabular}




\begin{tabular}{|c|c|c|c|c|c|c|c|}
\hline Time & & & & & & & \\
\hline $\begin{array}{l}\text { Prior } \\
\text { experiences }\end{array}$ & & & $X$ & & & & \\
\hline Year 1 & $X$ & $X$ & $X$ & $X$ & $X$ & $X$ & \\
\hline Year 2 & & $X$ & $X$ & $X$ & $X$ & $X$ & \\
\hline Year 3 & $X$ & & $X$ & & & $X$ & $X$ \\
\hline Post Year 3 & & $X$ & $X$ & & & $X$ & $X$ \\
\hline
\end{tabular}

\subsubsection{Identity as a teacher leader}

Martin did not perceive himself as a teacher leader when he started this program, although he had served in formal leadership roles. As he put it, he had been just 'filling up positions' (INT2). Though he was not initially confident in his leadership abilities, this grew as he took on new leadership roles and activities over the course of the program. These helped him shift his perspective on his own identity; as he stated, "I saw that I could be a leader" (INT 2).

Presently, Martin still defines his leadership through his roles as an instructional coach, pre service teacher mentor, member of the district planning committee, head teacher of the PF team in his school, and member of the district committee for assessment and learning. He described his leadership influence in these roles like 'concentric circles' affecting his immediate teacher colleagues at first, and then finally moving out to students. He felt his leadership was recognized by his administrators and colleagues, who viewed him as a passionate leader contributing towards school betterment; someone who is always ready to get involved; and a participatory leader who is ready to grasp any available leadership opportunity (INT 2). Martin credits the PD program with helping him recognize opportunities and become confident with his identity as a teacher leader.

I am a teacher leader, and I feel like I am a leader.[I] am a leader in our building, and in our district. I think that's a result again, to a great extent, due to the program... (INT 2) 


\subsection{Developing as a Teacher Leader}

\subsubsection{Case 1 - Brandon}

Brandon's process of becoming a teacher leader occurred through a synergy and alignment between his identity, leadership views and leadership practices (Figure 1 and 2). Though Brandon was successful in real estate and self-identified as a business leader, this did not translate directly into his experience as a teacher leader, and there were disconnects between his identity, views of leadership, and his practices (Figure 1). The PD program gave him tools necessary to address these gaps, and instilled confidence in his ability to be a teacher leader.

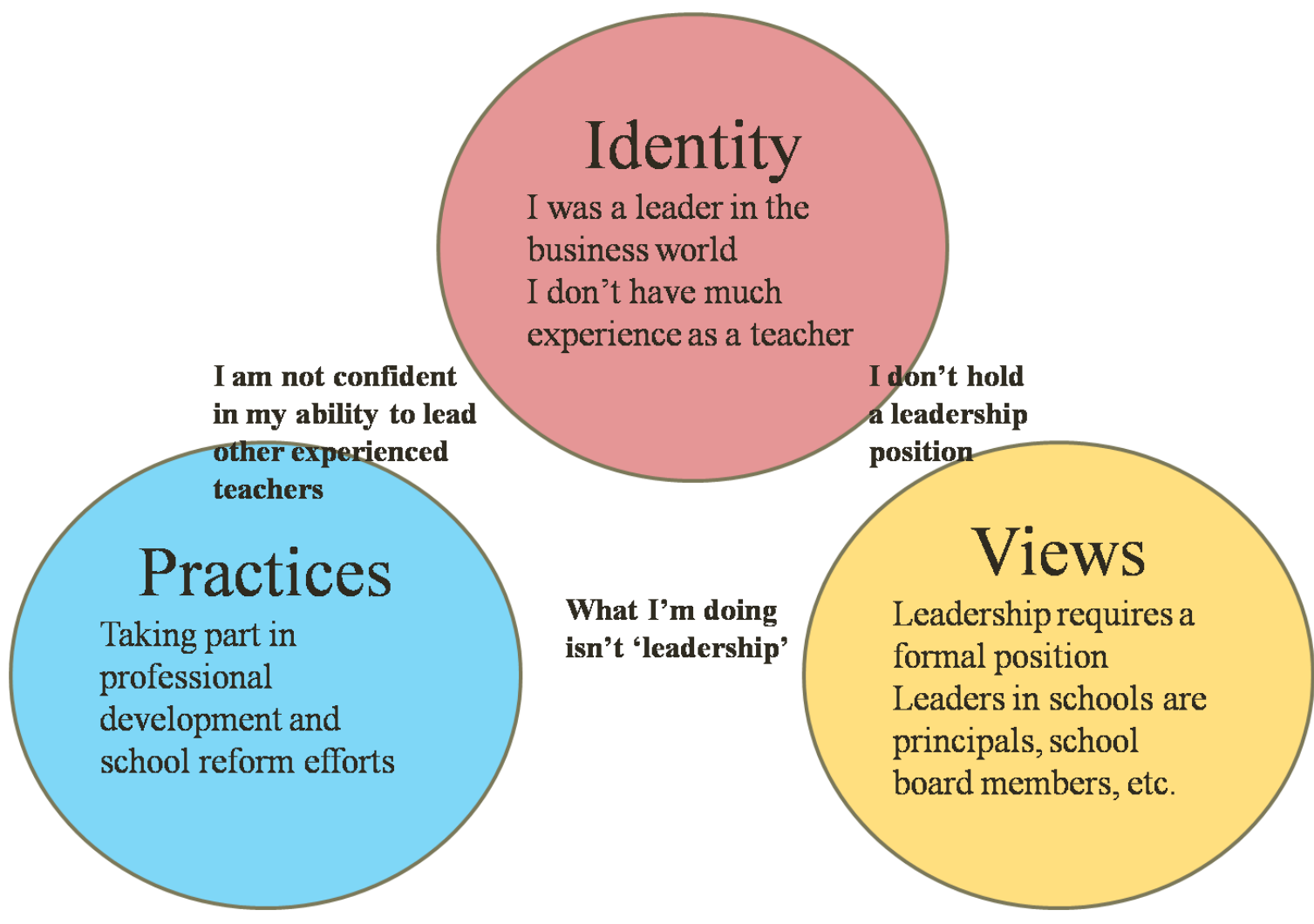

Figure 1.Brandon's disconnected teacher leadership components

Brandon viewed leadership to be always formal and he thought that he was not a teacher leader because he did not have any official position. The readings, discussions, and interactions he had in the program challenged this view, and helped him realize that leadership can be both 
formal and informal. This helped refute his belief that he could not be a teacher leader since he did not have any leadership position.

Similarly, although Brandon was engaged in what York-Barr and Duke (2004) would consider leadership activities, he did not perceive those practices to fall under the realm of leadership at the beginning. He was doing those activities simply as a teacher, and not within the scope of a position of authority. As he changed his leadership views, he started viewing his activities as falling under the realm of teacher leadership. For example, he thought that by challenging the status quo of traditional teaching and advocating for modeling pedagogy, he could support school change and improve student learning. By doing informal activities such as educating his colleagues about white boarding, modeling and helping students transition to this new style of teaching, he started expanding his leadership practices, bringing those into alignment with his views of leadership.

Brandon was not initially confident in his ability to lead other teachers who had been teaching for many years more than him. One of the reasons for low confidence was his unfamiliarity with the physics content, which was improved by his participation in the program. This in turn made him more confident as a teacher, which enabled Brandon to draw on his business experience to undertake leadership endeavors such providing school wide PD sessions for colleagues and convincing parents and other stakeholders to support the new freshman physics curriculum. His confidence as a teacher leader was boosted by the feedback from colleagues and administrators for these efforts.

Brandon's process of becoming a teacher leader can be understood as the process of aligning his views of leadership, identity, and practices. Figure 2 illustrates this process, and the 
way in which Brandon's participation in the PD program facilitated the alignment process by challenging his ideas and supporting his engagement in leadership practices.

\section{Brandon}

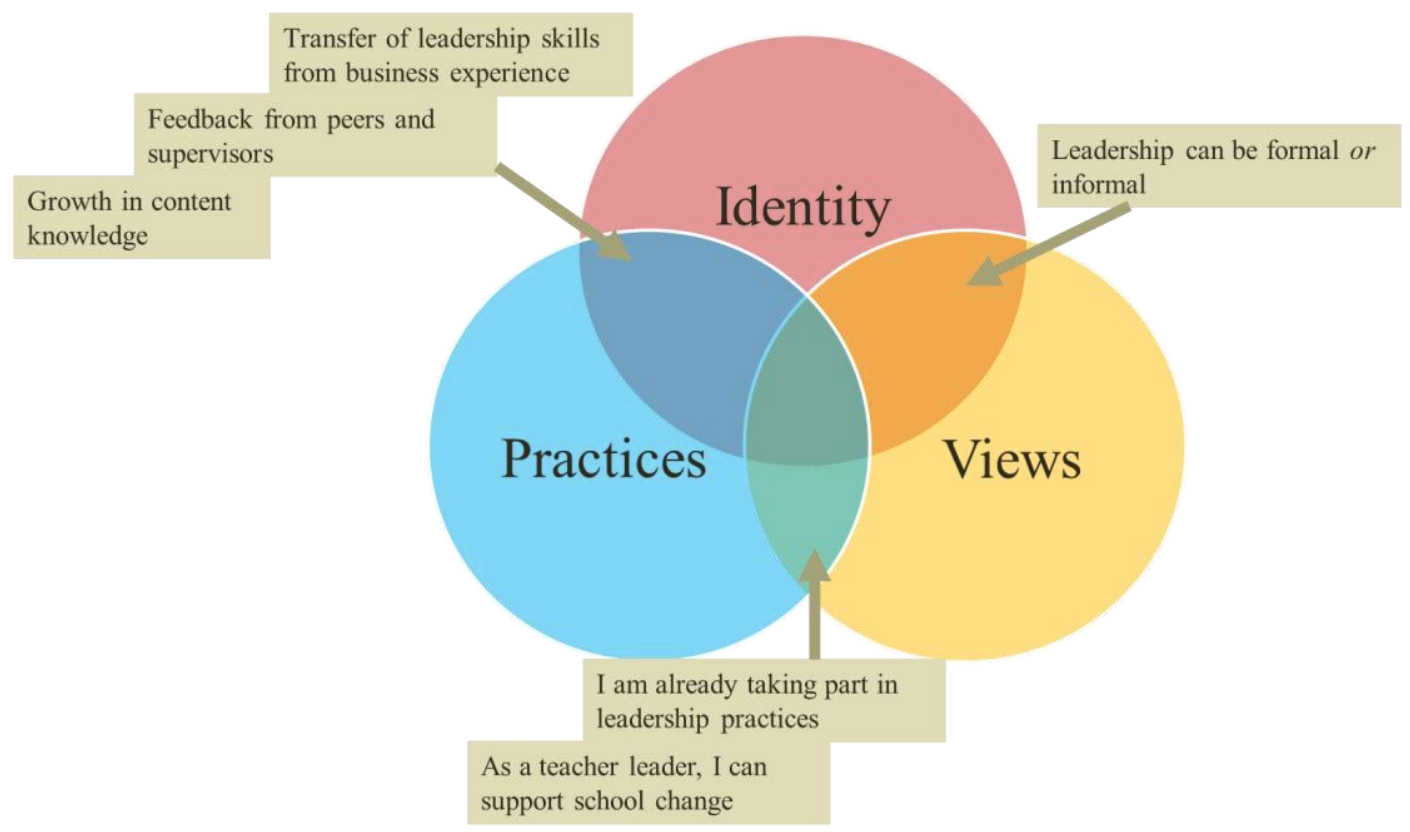

Figure 2.Brandon's teacher leadership development

\subsubsection{Case 2: Elisa}

Elisa's teacher leadership development can also be described based on the process of transformation of her leadership views, identity and leadership practices. Prior to being a teacher, Elisa served in the army. Although she had a leadership position, she never perceived herself as capable enough to lead the veterans who were more experienced than her. Similarly, she did not view herself as a teacher leader due to lack of confidence in her ability to lead and the roles and positions in which she served (Figure 3). 


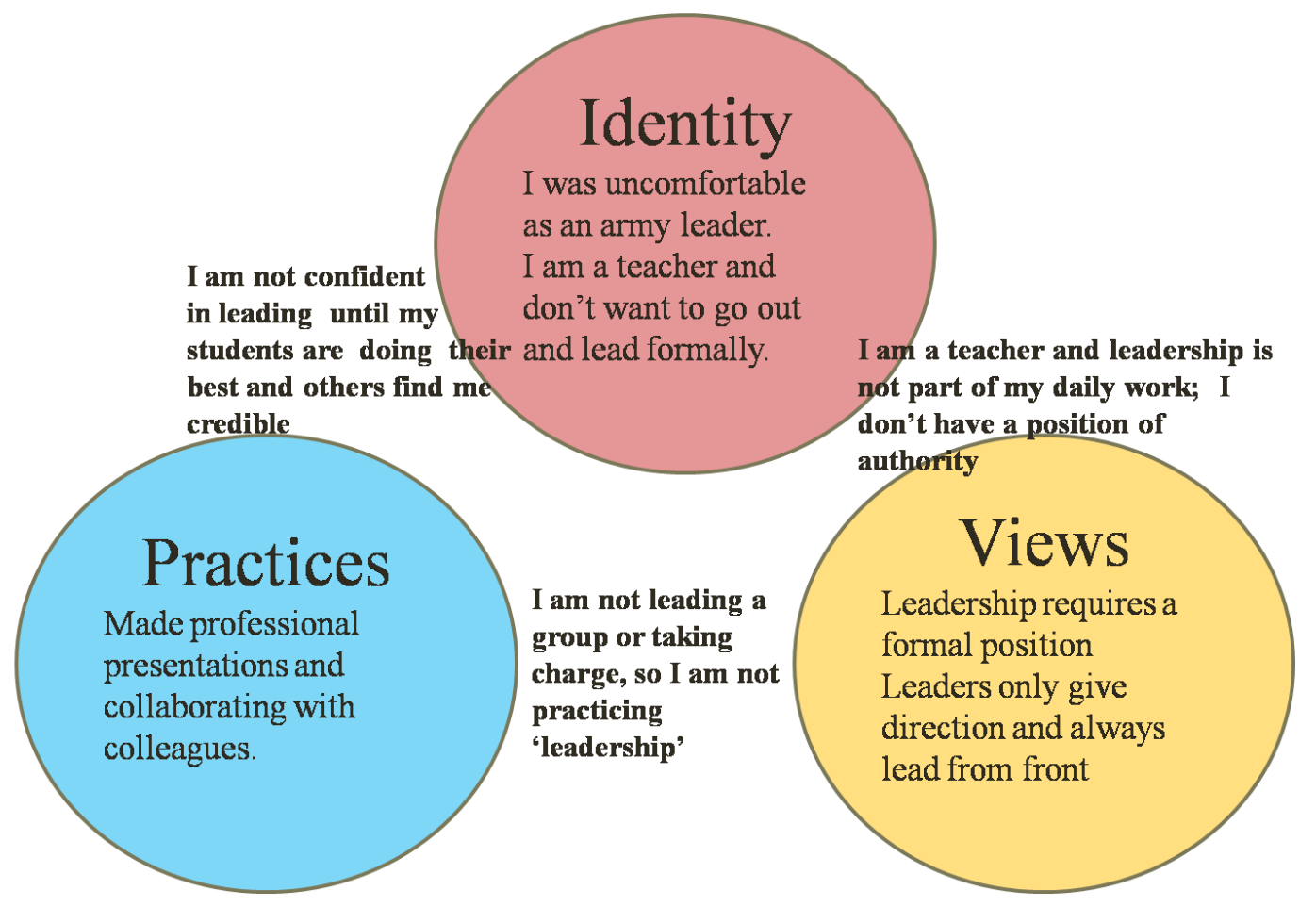

Figure 3.Elisa's disconnected teacher leadership components

Elisa was of the view that leadership always requires a position of authority and that leaders always lead from the front and direct others. These preconceptions and perceptions created barriers, which prevented her self-perception and development as a teacher leader. As she participated in the leadership sessions, she a realized that leaders also lead informally, sometimes by working behind the scenes. This created a bridge between her leadership views and identity, as she understood that she could be a teacher leader even though she did not have a formal position of authority. Furthermore, this change in view also contributed to closing the gap between her views and leadership practices.

Elisa also did not consider any of her teaching responsibilities as falling under the realm of leadership, because she was not leading a group from the front. Yet, Elisa's prior activities before joining this PD fell under the scope of teacher leadership according to the dimensions provided by York-Barr \& Duke (2004). The transformation in her leadership views helped her 
connect her current practices with those of being a leader, as she came to see that leadership could be practiced as a teacher by working at the grass roots level. For example, she initiated a successful science outreach program in her school on her own, versus having a formal position to lead it.

Elisa thought of herself as 'teacher' and confined her roles to within the classroom at the beginning as she entered the PD program. In the beginning, her view of teacher-leadership was tied to the perception of those around her: she did not feel confident unless her students were doing the best in class and others found her credible. Gradually, as a result of learning more about content and pedagogy and seeing improvements in her students' performance, she gained confidence and she started seeing herself as a teacher leader. She eventually did pursue formal leadership roles within the state science teachers association, and received recognition by others for her efforts. Figure 4 depicts how her participation in the PD program helped facilitate this alignment between her identity, views of leadership, and practices.

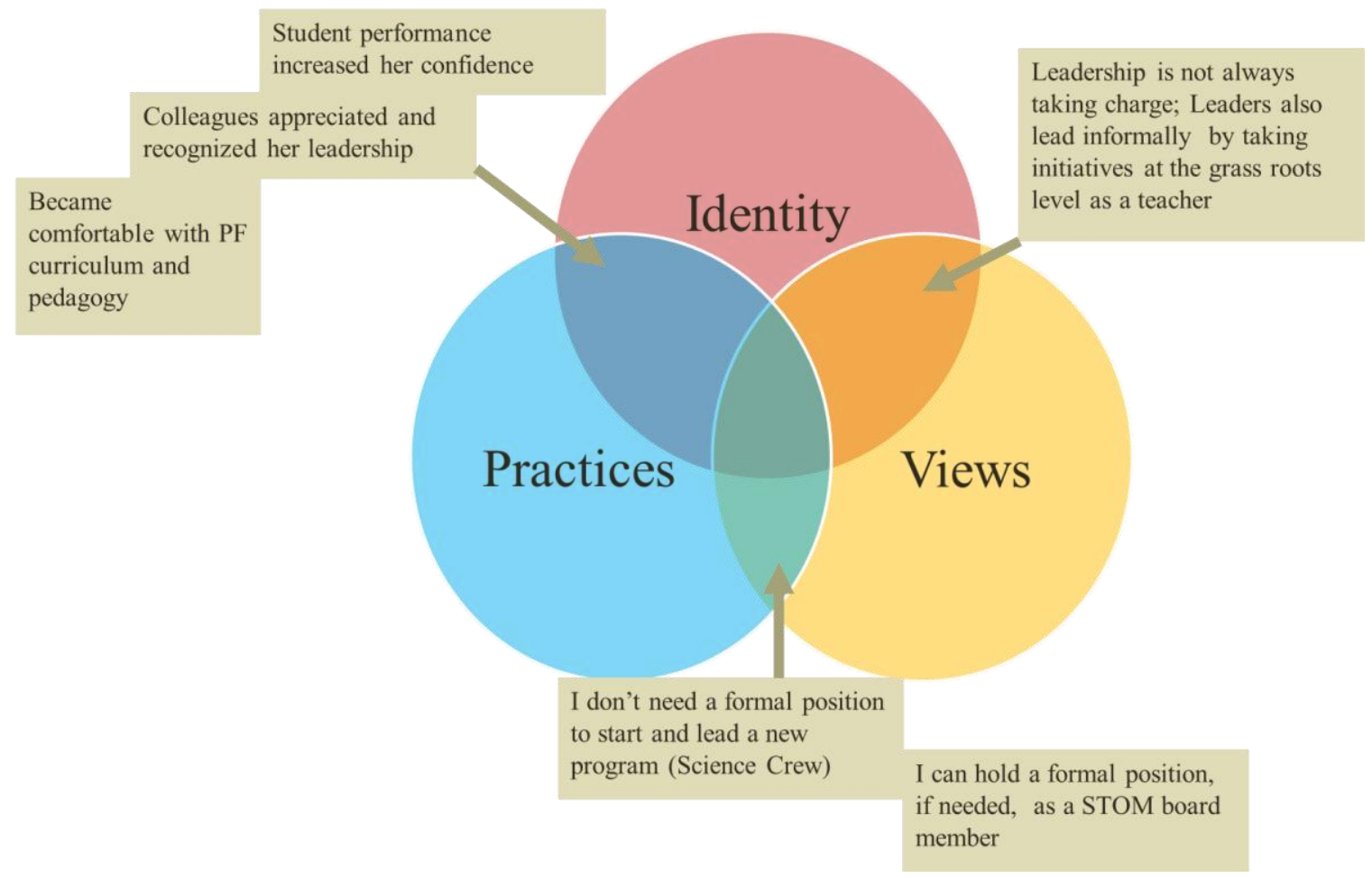


Figure 4. Elisa's teacher leadership development

\subsubsection{Case 3: Martin}

Similar to the other two participants, Martin developed as a teacher leader by aligning his identity, leadership view, and leadership practices. Unlike Brandon and Elisa, he had been a teacher from the beginning, and was further along in his career. Yet, he too did not see himself as a teacher leader, exhibiting disconnects between his identity, views of leadership, and practices (Figure 5). Attending the PD program supported Martin in transforming his leadership views, expanding his horizon of leadership practices, and building his confidence as a teacher leader.

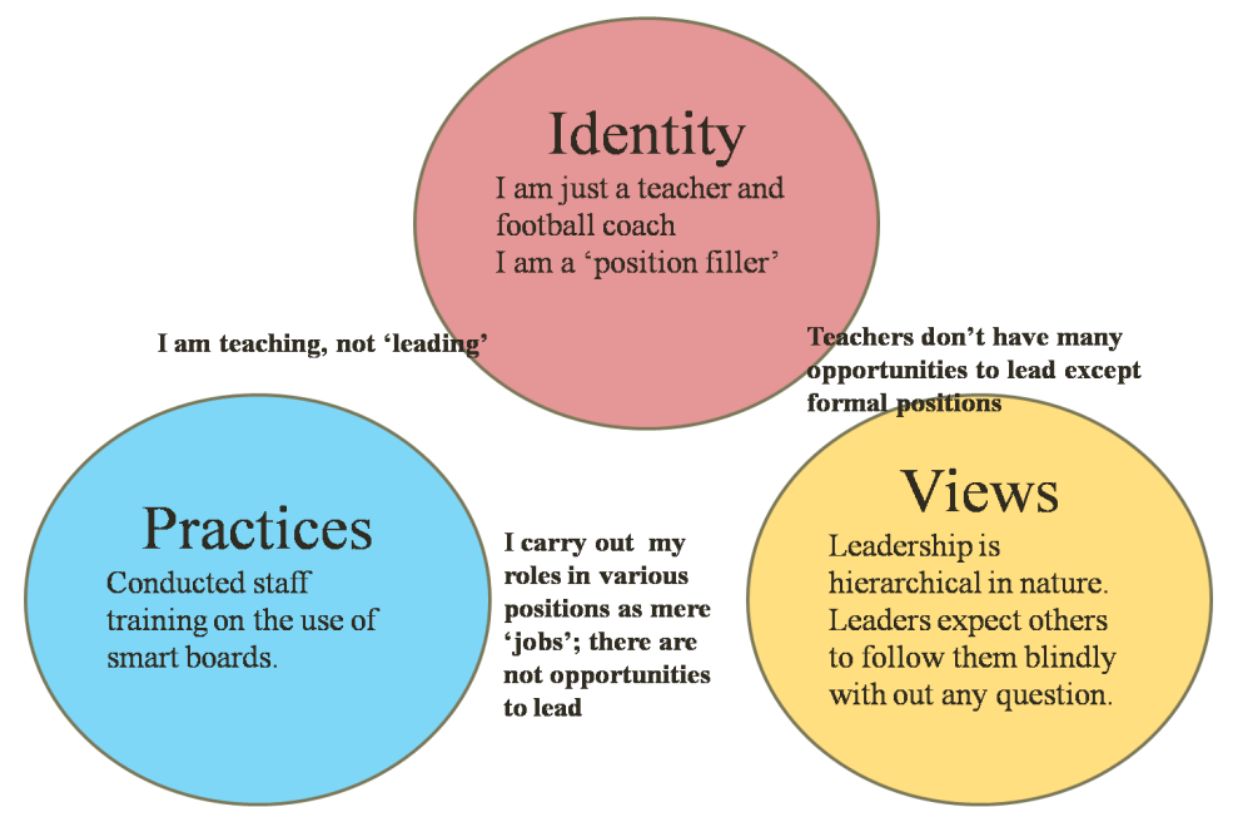

Figure 5. Martin's disconnected teacher leadership development components

Martin's general notion of leadership posed barriers to his self-perception as a teacher leader and his development. Martin viewed leadership as hierarchical in nature and thought that leaders always lead with authority, demanding absolute adherence from the followers. As such, he believed teachers did not have many opportunities to lead unless they had formal positions. This prevented him from thinking that he could be a teacher leader; even though he was department chair, since his actions in this position did not reflect that view. However, taking part in the PD 
exposed him to broader ideas of leadership, increased his awareness of others' leadership views, and gave him a platform for reflection. All these helped him realize that teachers can be leaders in the way they identify and utilize leadership opportunities that arise. In becoming a teacher leader, he ultimately started encouraging and empowering others to become teacher leaders as well. The process by which the PD program facilitated this shift in Martin's identity and the alignment with his practices and views of leadership is depicted in Figure 6.

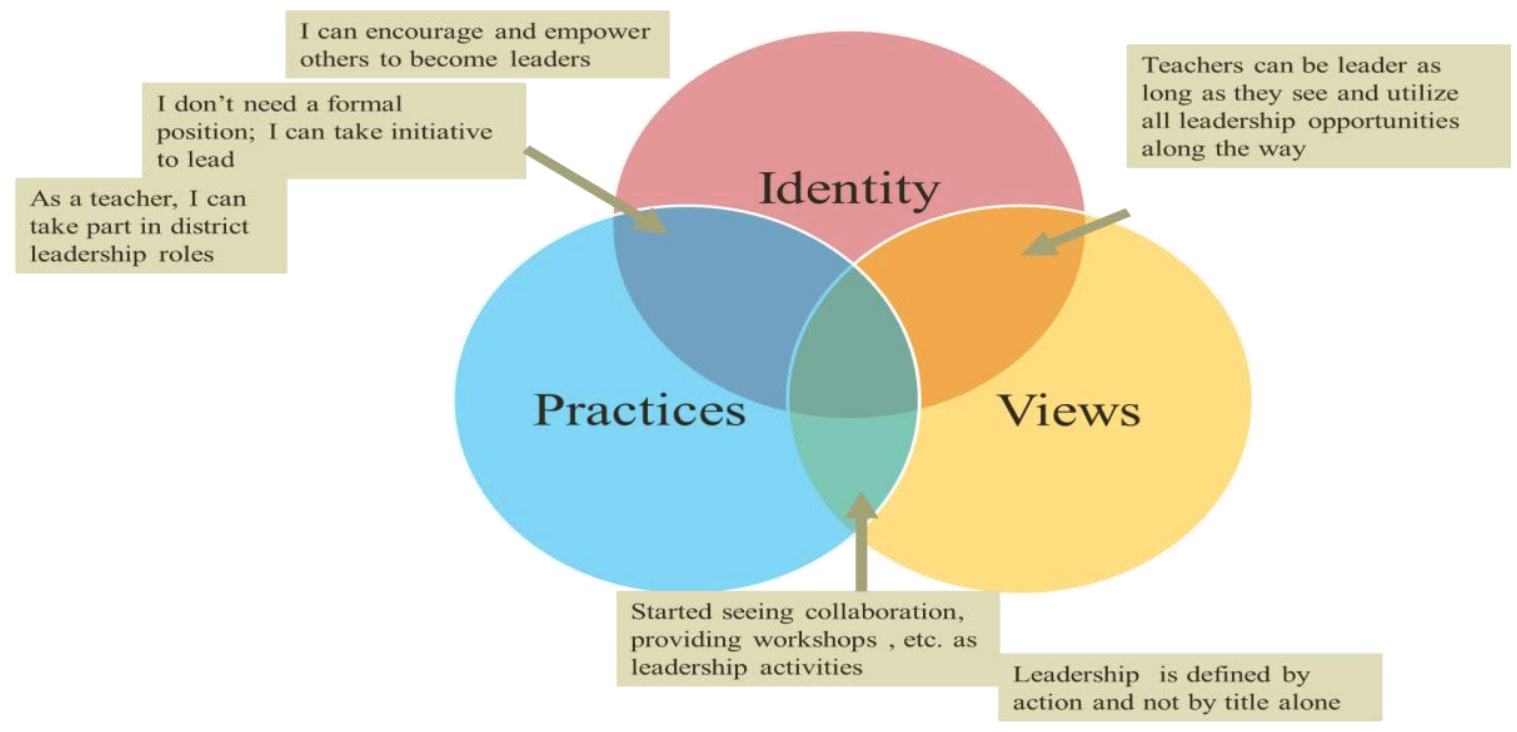

Figure 6. Martin's teacher leadership development

\subsection{Cross case analysis}

There were similarities and differences in the leadership pathways Brandon, Elissa, and Martin took. This section compares and contrasts the participants' leadership identity development trajectories spread across their leadership practices, views of leadership, and identity as teachers and leaders. We address these in terms of eight major areas: (1) expansion of teacher leadership views, (2) expansion of dimensions of teacher leadership practice, (3) leading within and outside the classroom, and (4) leadership development priorities. 


\subsubsection{Expansion of teacher leadership views}

Throughout this program Brandon, Elisa and Martin were able to broaden and redefine their conception of teacher leadership and overcome narrow ideas that precluded them from viewing themselves as teacher leaders. Similar to findings reported by Grant (2006), our three case participants initially held views of leadership as a formal position, requiring a title and authority. Brandon had experience with the business world and he thought leadership was always 'top-down'; Elisa, with army leadership experience, associated leadership with taking charge; Martin had been a football coach and believed entirely in 'leader-follower' relationship where the leader, similar to a coach, would give instructions and followers had to follow it unquestionably. However, expanding their conceptions of leadership allowed them to pursue their pathways toward teacher leadership.

Key to this was their recognition that leadership could be both formal and informal in nature, and that holding a formal leadership position by itself is neither a necessary nor sufficient condition for one to be a leader. Brandon viewed leadership as title independent, Elisa highlighted that a leader never ceases to be a leader although s/he may not always be at the forefront, and Martin emphasized that a leadership title only gives access to leadership opportunity.

All three teachers credited the PD with changing their conception of leadership. Elisa highlighted how talking with other teachers about various kinds of formal and informal leaders helped her understand the importance of grass root level leaders. Martin also identified the significance of reflection, which prompted them to "look at [their] definition of leadership and reflect on why we thought [that]" (INT 1).

These results do not indicate any stark difference with regard to change in teacher leadership views between the teachers, despite the differences in their career stages and teaching 
experience, in contrast to Day (1999) who found that teachers differed in their views of leadership according to whether they were novice, experienced, or an expert. Our findings are more similar to those of Emira (2010), who found that the length of teaching experience of teachers may not contribute to their teacher leadership views and minor discrepancies may be due to individual differences. Nonetheless, the fact that our participants went through the same PD program might have contributed to some extent to the similarities in their leadership views.

\subsubsection{Expansion of dimensions of teachers' leadership practice}

All the participants expanded their repertoire of leadership activities within the various dimensions of practice of teacher leaders (York-Barr \&Duke 2004) as they developed their teacher leadership identity. Among the three, Martin expanded his horizon the most followed by Brandon and Elisa. Martin's leadership activities fell under only one dimension of PD of colleagues before he joined this program but it expanded to all the seven dimensions by the end of three years. Brandon, on the other hand had leadership experiences falling in two of those dimensions initially, but extended to six of them by the end of third year. Finally, Elisa expanded from at least three dimensions to six. While all teachers' leadership practices expanded, only Martin participated in all seven dimensions of leadership practice identified by York-Barr and Duke (2004). He alone mentored pre-service teachers from the local university; however, this may be more a consequence of an opportunity available to him, but not the others, as his school was in close proximity to and had a partnership with a teacher education program.

The PD contributed in various tangible ways, which helped the teachers practice leadership. Martin offered "I honestly believe that the other leadership opportunities I have taken advantage of this year have been as a result of the spark initiated by this course and my action plan” (FR Y1). Another contribution was identified by Elisa as encouragement from PD facilitators to practice leadership outside her classroom, or the "push to get involved within [her] 
school and district" (INT 1) she got from the leadership sessions. In a similar way, Brandon highlighted how the curriculum materials (books, rationales to invert science sequence, graphs showing why teaching of physics at freshman level is needed) provided by the program helped him to expand his leadership activities in terms of aligning his curriculum.

Our results in regards to the expansion of leadership practices by teachers not only confirm Grant's (2006) findings, but also that of other studies (Hofstein et al., 2004; Ross et al., 2011; Taylor et al., 2011). For example, Luft et al. (2016) found that as time passed their participants increased taking part in leadership activities. Similarly, Howe and Stubbs (2003) found that teachers moved into new roles as teacher leaders by doing activities such as writing curriculum materials, delivering workshops, sponsoring science clubs, serving in city councils to address environmental issues, participating in science teacher associations, etc. Although Howe and Stubbs did not examine their participants' leadership activities in terms of York-Barr and Duke's dimensions of leadership practices, their findings nevertheless resonate with those of our study in that teachers developed as leaders by expanding their scope of leadership practices.

While analyzing data, we encountered several activities in which participants were engaged that did not fall in any of the seven dimensions of leadership practice of our conceptual framework, but nevertheless they were related to teachers' leadership identity development. Activities such as pursuing graduate level coursework, interning with the principal, reading leadership literature, taking firm steps to improve teaching skills (e.g., videotaping their own teaching), reflecting about personal leadership styles and how to improve, and accepting feedback from others fell into this category. York-Barr and Duke's (2004) dimensions of leadership practice points towards various leadership activities teacher leaders do and various roles they play. Thus, these activities cannot be viewed as a particular type of leadership 
practice, but rather as a form of personal growth and development. For example, working on a principal or superintendent certification course and interning with a principal would pave the way for a teacher becoming a principal or superintendent. Similarly, seeking and accepting feedback from others could support teachers' leadership practices in relation to coordination and management issues. Therefore, personal growth activities are crucial in conjunction with various teacher leadership practices for a holistic development of teacher leader identity.

The importance of personal learning and growth has been highlighted by other studies as well. Such as with Komives et al (2005), who made a separate category for 'Developing Self' in their leadership identity development model. These authors pointed out activities related to deepening self-awareness, building self-confidence, establishing interpersonal efficacy, the expansion of personal motivation, and the application of new skills. Some of these resonate with what our participants were doing under the realm of personal development. However, our conception of self-development in relation to teacher leadership contrasted with what was described by Hofstein et al (2004). These authors highlighted the personal development aspects of Bell and Gilbert's (18994) PD model of science teachers. Hofstein et al (2004) described personal development in reference to affective development that involved attending to personal feelings about personal growth and about being a teacher and a leader. In contrast, our data regarding teachers' self-development was not limited to affect.

\subsubsection{Leading within and outside the classroom}

Brandon and Elisa both started leading within the classroom and slowly extended their sphere of influence within and outside the school, and to the immediate community and beyond. Brandon felt his students were not challenged enough and felt they had potential to excel and do better in science. So after attending the academy, he started promoting the pedagogical strategies he learned in the PD among his colleagues. A major part of his leadership activity encompassed 
working with colleagues to help them learn white boarding strategies, giving teaching demonstrations in other classrooms, and working with the principal on overall student improvement issues and assisting in interviewing new hires. Elisa was very explicit about her concern about improving her own teaching from the very beginning. She thought that "How can others take our ideas if I am not having good results [implementing them]?” (LSE). After directing her leadership efforts within her own classroom the first year, she expanded beyond her classroom in the second year by mentoring a colleague, serving on school committees and collaborating with other teachers to implement new pedagogical strategies. She also moved beyond her school and got "involved in higher level[s] of educational leadership" (LSE) by serving as a board member for the state science teachers' association.

Martin on the other hand, focused his leadership efforts outside of his classroom from the very beginning. He formed a group of colleagues to observe each other's teaching and give feedback, and promoted implementation of the PF curriculum within the school district. $\mathrm{He}$ carried out district-wide workshops for teachers, met with the local media to inform the community about the success of the program, and promoted freshman physics to school district leaders. After serving on schoolwide committees, he expanded to district level committees; he currently serves on a district planning committee, district wide assessment-for-learning leadership team, and district wide project based learning team.

Angelle and DeHart (2011) said that the idea of teacher leadership, often reflected by the realm of its practice, is understood differently by teachers based on their years of service. Our results contradict their assertion in regard to ideas of teacher leadership, as participants initially held very similar views of teacher leadership, regardless of their years of service. However, our results support their assertion in regard to practice, as Brandon and Elisa started leading inside 
their classrooms while Martin, who had more experience, started leading outside his classroom and school. Furthermore, the authors also said that compared to newer teachers, "leadership training for experienced teachers may enhance their desire to step out of their classroom and take on a larger school role" (p. 156). This again resonates to what we found with respect to Martin, the most experienced teacher among our participants.

\subsubsection{Leadership development priorities}

As Brandon, Elisa and Martin developed as teacher leaders, they had their own unique priorities. While traversing in their individual pathways of teacher leadership identity development, they found their own leadership niche by prioritizing according to their interests and the unique needs apparent in their respective contexts. For example, although all three participants carried out activities related to PD of colleagues, they did this in different ways. Elisa first prioritized mastering new pedagogy in her own classroom; Brandon prioritized securing resources that would enable his colleagues to adopt new pedagogy; and Martin formed a peer observation group that empowered his colleagues to be leaders as well in supporting one another's instructional improvement.

The school context of our three case participants were very favorable with regard to supporting their individualized teacher leadership development. Brandon, Elisa, and Martin each talked highly about the support they received from their principals and other administrative staff. This is perhaps unique, given the literature documents a number of contextual factors that impact teachers' development as leaders (Angelle \& DeHart, 2011; Grant, 2006; Jolie Mayer-Smith, 2003; Wenner \& Campbell, 2016); however it is reflective of a larger commitment of these schools to participate in the program and implement a freshman physics course.

In their review of teacher leadership literature, Wenner and Campbell (2016) found that contextual factors like "administrative support, climate and structural factors, responsibilities and 
recognition" (p. 20) either facilitated or inhibited teacher leadership development. Similarly, Angelle and DeHart (2011) described how the leadership vision held by a school/ school district affects teachers' commitment both within and outside the classroom. In our study, the leadership activities of the individual teachers were consistent with the schoolwide commitment to the program.

\section{Conclusion and Implications}

Although teacher leadership has been viewed as a crucial component for successful teaching and learning (Lieberman \& Miller, 2007), there is little literature on the process of teacher leadership development. Teacher leadership development is a complex phenomenon (York, Barr \& Duke, 2004). This study investigated the teacher leadership development process of three high school science teachers with varying years of teaching experience. Based on the findings described in the last section, the following assertions can be made about their process of teacher leadership development - teachers widen leadership views as they develop as teacher leaders; teachers expand their scope of leadership practices as they develop as leaders; newer teachers, compared to veterans, tend to start leading within the classroom and then transition to leading outside the classroom; and teacher leadership trajectories depends on the priorities of the teacher and her/his context. Furthermore, as a main contribution of this study, we will propose a model depicting the process of teacher leadership development.

\subsection{Leadership identity development}

Our experiences with this investigation brought forth the complex nature of teacher leadership identity development. All of our participants started with the self-perception that they were not teacher leaders and finally ended up recognizing themselves (and being recognized by others) as such. In regards to the nature of this development, all three were unequivocal in saying 
that this development was gradual and time dependent, versus being an abrupt change. Our results findings suggest that they started with low confidence and slowly gained confidence as they met with success in their various teacher leadership roles and activities. Their progress reports for their leadership action plans (mid-year and final year) documented how the accomplishment of their action plan goals helped them gain confidence. It should also be noted here that sometimes a teacher's confidence is associated with their comfort in teaching the content and supporting student success in their own classroom. The two newer teachers had less background and experience with teaching the physics content and hence their associated comfort level was also low. Specifically, Brandon had not taught physics courses earlier which affected his level of confidence in teaching his courses and Elisa was not comfortable with the pedagogy and reestablished way of teaching physics within the PD program.

Although teachers' leadership identity development was gradual, there were instances of identity shifts in all of three cases. For example, statements by participants such as "I have changed and become more confident and recognize leadership opportunities" and "I have changed as I developed as a leader - I am more vocal now" clearly depict their identity transformation. All participants mentioned the presence of a model leader - a personification of the leadership characteristics they valued. Moreover, the identity of a person is not limited to her/ his self-perception; the viewpoint of others is also significant. In this study, feedback, recognition, and support from colleagues and PD staff were also crucial to participants' identity development. Colleagues' and other fellow teachers' recognition not only boosted participants' confidence, but also enhanced their feelings of credibility and competence as teacher leaders. This was directly evidenced by blog conversations in which colleagues acknowledged our participants' credibility and their leadership qualities. 


\subsection{Leadership development process}

Based on our study, we suggest that the process of teacher leadership development can be characterized as a synergistic interplay of an individual's views of leadership, engagement in leadership practices and identity development. As a result of this investigation, we propose a model for teacher leadership (Figure 7) that highlights the interplay of these three components in the process of teacher leadership development.

In our model, we have assigned leadership views as the base, followed by leadership practices, and finally how both affect the development of teacher leadership identity. Although arranged this way, the model does not imply a pyramidal structure starting with leadership views and ending in leadership identity via leadership practices at this point. What becomes critical within this model is the identification of the mechanisms and means by which all three components are brought into alignment. All the participants of this investigation took part in a PD program, which contributed in transforming their leadership views, developing their leadership identity, and expanding the horizon of their leadership practices. Their teacher leadership views were broadened by the leadership literature they read, the discussions with others regarding their leadership views, and the reflective practices promoted by the leadership course in which they were enrolled. PD sessions helped them identify leadership opportunities, which they did not 'see' as leadership earlier, using York-Barr and Duke's (2004) seven dimensions of leadership practice. The leadership action plan helped them map out and execute a series of leadership activities each year for three consecutive years. These instances, and others, can be represented in the model as the forces acting on each circle to bring all three into alignment. 


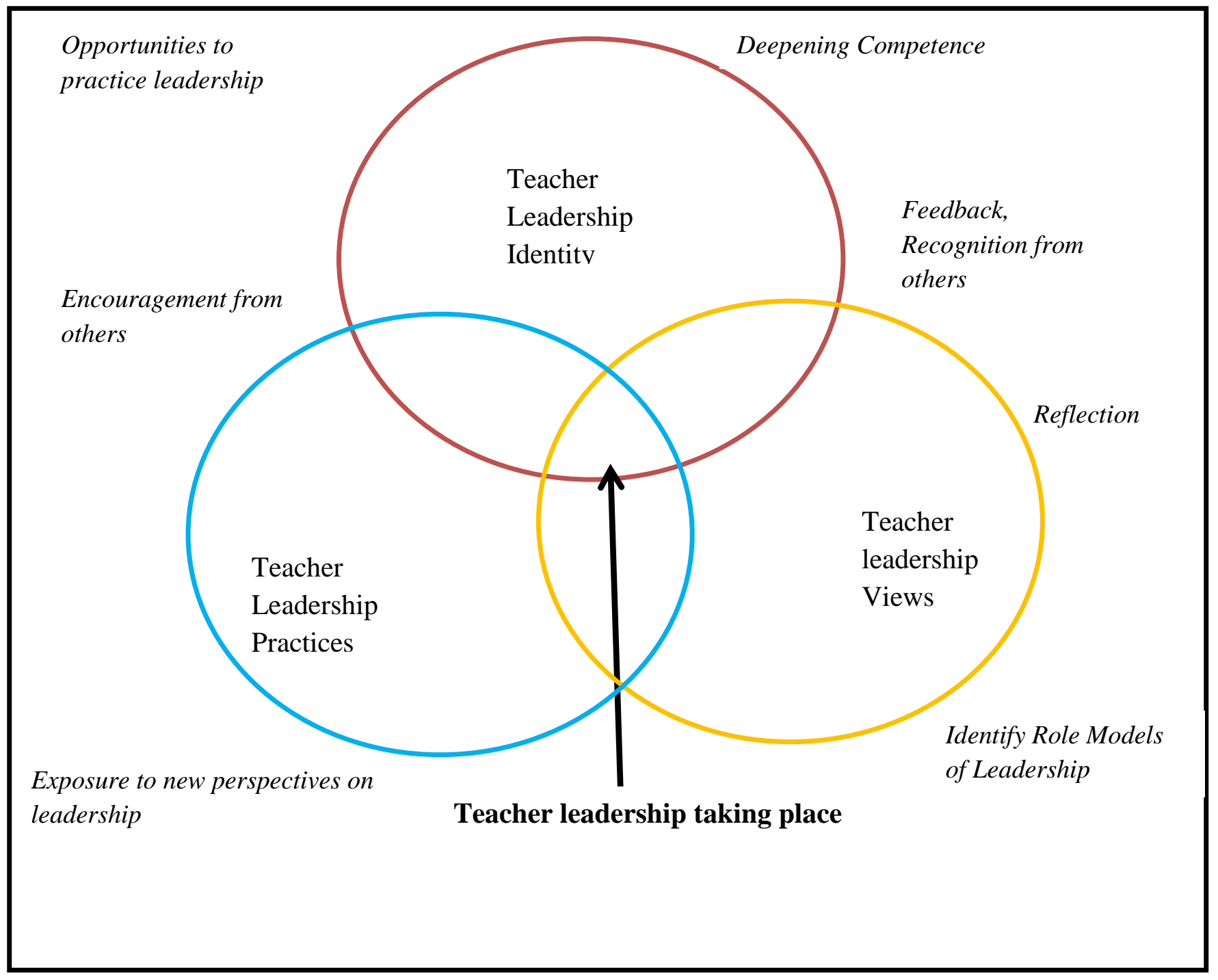

Figure 7. Teacher Leadership development process

A persistent question in the literature is the point at which teachers may be considered 'leaders', particularly given identity is an ongoing construction. This model addresses that question, while maintaining a view of identity as dynamic. According to our model, teacher leadership occurs when all of these components become aligned with each other. This alignment is facilitated by a variety of factors; including opportunities to practice leadership, develop competence, receive feedback, engage in reflection, be exposed to new ideas, identify role 
models, and interact with others. The three components each contribute to the teacher leadership development process, as it occurs within the alignment of the three. This model does not promote any particular aspect to be more important than another; however, for convenience, we will use the model to describe a teacher leader's developing by starting with views of teacher leadership.

To start with, a teacher is expected to have some prior ideas about a teacher leader/ leader and teacher leadership/leadership. A teacher also adds to this repertoire as s/he learns new things, views other teacher leaders, works with other teacher leaders, and through her/his personal experiences. This broadening of the view of teacher leadership is recommended by Authors (2012). For example, one of the teachers (Brandon) had the view that leaders take initiative and step up when something needs to be done and others do not take the lead. This component is crucial because an understanding of what teacher leadership is and what a teacher leader does, helps a teacher to be aware of leadership practice opportunities irrespective of their years of experience (Angelle \& DeHart 2011).

The next component is leadership practices. This encompasses various activities teachers do as they develop as leaders, such as those identified by York-Barr and Duke (2004). An intersection occurs when they do the same activities, which they consider to be leadership and vice versa. For example, Brandon viewed taking initiative to be a leadership characteristic and he himself took lead to educate his colleagues about various modeling and white boarding strategies.

The last component is teacher leadership identity- a dynamic characteristic dealing with the perception of self and others. A teacher may perceive her/himself as a teacher leader in various ways, however an intersection occurs when s/he views herself/himself as a leader due to the leadership activities they do or how they define 'leadership'. As in this example of Brandon, 
he ultimately views himself as a teacher leader due to all the initiatives he takes which he viewed as what teacher leaders do. Thus, this leadership identity becomes stronger and better defined as they successfully practice more such leadership activities that they think fall in the teacher leadership realm.

These components are related and are influenced by each other. A teacher may have idealistic views of leadership, but if they do not enact those views into leadership practices, then it is does not contribute in their leadership development process. Those thoughts and views just remain abstract ideas. Author et al (2012) found this mismatch between leadership views and leadership practices and stated that "there exists an interesting dichotomy between the activities that teachers engage in and those they perceive as constituting leadership" (p. 17). This misalignment can ultimately prevent teachers from seeing themselves as teacher leaders; that is, developing an identity as a leader. On the other hand, and as described in the previous paragraph, the alignment between these two aspects helps the identity development of teacher leaders. In a reverse manner, if we start from the identity aspect of an individual teacher, s/he cannot perceive her/himself to be a teacher leader until and unless they practice teacher leadership through various activities. As detailed earlier, self-perception is dependent on self-confidence, which in turn happens via successful teacher leadership practice (Gonzales \& Lambert, 2001).

\subsection{Implications of the study}

The findings of this investigation have implications for professional developers, teacher preparation, school administrators, and educational researchers.

\subsubsection{Implications for professional developers}

Based on our study, in order to help develop teacher leaders, PD should help teachers align their beliefs, actions, and identities by (1) broadening teachers' views of leadership (i.e., defining 'teacher leadership'), (2) expanding teachers' awareness of opportunities to lead (i.e., 
finding a personal niche for leadership), and (3) supporting them in forging identities as 'teacher leaders'. Prior to participating in this PD program, our participants considered formal leadership to be the only form of teacher leadership. They viewed teachers with official leadership positions, principals and administrators to be the only leaders in the school arena. PD should help teachers understand that leadership can be embedded in their day to day practices and does not require abandoning their teaching responsibilities Familiarizing teachers with various options in terms of leadership activities could be introduced by discussing the varied dimensions of practice of teacher leaders (York-Barr \& Duke, 2004).

Although they went through a common process of teacher leadership identity development, our participants did so by pursuing different pathways according to their experience, priorities and contexts. This clearly indicates that there is no single 'panacea' or a pre-fixed pathway for leadership development. Programs should be flexible enough to accommodate participants' contexts, personal leadership development priorities, and career stage. For example, in this particular program, the action plan was based on a leadership goal selected by teachers, rather than having 'leadership' be defined as a set of specific task expectations by the program.

As endorsed by our model, professional developers should take into account three aspects of teacher leadership development- views, practices and identity—and help participants bring those into greater alignment. Workshops should be designed to synchronize teachers' views with opportunities to practice various leadership activities and reflect on one's growth as a 'teacher leader'.

Additionally, programs should take into account how colleagues and others' views are important to teachers' leadership identity development. The blogging platform used in this 
program, in particular, provided key identity resources and opportunities for participants to engage in identity work (Authors, 2014). Feedback from peers reassured Brandon, Elisa and Martin that they were making progress on their leadership pathways. Discussions about challenges and successes helped them develop their own leadership practices. Similarly, discussions about what it means to be a 'leader' helped broaden their views of teacher leadership. Through reflection, participants brought their views of leadership, leadership practices, and identities into greater alignment.

\subsubsection{Implications for school administrators}

As evident from our findings and supported by other studies, context plays an important role in teacher leadership development. Furthermore, our results also indicate the importance of self-confidence, support and suggestions of colleagues in leadership identity development, and the ability to practice leadership. Principals, superintendents and other administrators should strive to create conducive environments within schools for teacher leadership development. Part of this will require administrators to be aware of various opportunities for teachers to serve as teacher leaders. (For example, Martin's awareness of leadership opportunities helped him support others in capitalizing on these opportunities.) They should encourage teachers to take on leadership roles, include them in various decision making procedures regarding school issues, pair up novice teachers with established teacher leaders, and give equal recognition to both formal and informal leadership.

\subsubsection{Implications for educational researchers}

The leadership development process model we have proposed describes how a teacher develops into a teacher leader through alignment of their leadership views, practices, and identity. Further research is needed to validate this model against a larger sample of teachers at different career stages and in different contexts. 
Our investigation showed that teachers developed their identity as teacher leaders by practicing leadership within and outside their classroom and school. Our study, however, did not assess the impacts of their leadership practices. Additional research is necessary to understand how these teachers and their activities influence their students, colleagues, and communities. This would also provide evidence of the broader impacts of the PD program beyond its immediate impacts on participants. 


\section{Reference}

Adams, D., \& Gamage, D. T. (2008). A study of leadership effectiveness in a large VET institution in Australia. International Journal of Educational Management, 22(3), 214228.

Angelle, P. S., \& DeHart, C. A. (2011). Teacher perceptions of teacher leadership: Examining differences by experience, degree, and position. NASSP Bulletin, 95(2), 141-160.

Atkinson R.(1998). The Life Story Interview. Thousand Oaks,CA: Sage.

Author, 2011 [details removed for peer review]

Author, 2012 [details removed for peer review]

Author, 2014 [details removed for peer review]

Author, 2016 [details removed for peer review]

Barth, R. S. (2001). Teacher leader. Phi Delta Kappan, 82 (6), 443-449.

Beachum, F., \& Dentith, A. M. (2004). Teacher leaders creating cultures of school renewal and transformation. The Educational Forum, 68 (3), 276-286.

Blackman, A. (2010). Coaching as a leadership development tool for teachers. Professional Development in Education, 36(3), 421-441.

Bogdan, R. C., \& Biklen, S. K. (2007). Qualitative research in education: An introduction to theory and methods. New York: Pearson.

Carver, C. L. (2010). Mentors coaching principals in instructional leadership: The case of Rebecca and Ramon. Journal of Cases in Educational Leadership, 13(2), 39-46.

Collay, M. (2006). Discerning Professional identity and becoming bold, socially responsible teacher-leaders. Educational Leadership and Administration: Teaching and Program Development, 18, 131-146.

Crowther, F., Ferguson, M., \& Hann, L. (2002). Developing teacher leaders: How teacher leadership enhances school success.Thousand Oaks, CA: Corwin Press.

Darling-Hammond, L., Bullmaster, M. L., \& Cobb, V. L. (1995). Rethinking teacher leadership through PD schools. The Elementary School Journal, 96, 87-106. 
Emira, M. (2010). Leading to decide or deciding to lead? Understanding the relationship between teacher leadership and decision making. Educational Management Administration \& Leadership, 38(5), 591-612.

Fairman, J. C., \& MacKenzie, S. V. (2014). How teacher leaders influence others and understand their leadership. International Journal of Leadership in Education, 18(1), 61-87.

Frost, D. (2012). From professional development to system change: teacher leadership and innovation. Professional Development in Education, 38(2), 205-227.

Gee, J. P. (2000). Identity as an analytic lens for research in education. Review of Research in Education, 25, 99-125.

Ghamrawi, N. (2011). Trust me: Your school can be better -- A message from teachers to principals. Educational Management Administration \& Leadership, 39(3), 333-348.

Gonzales, S., \& Lambert, L. (2001). Teacher leadership in professional development schools: Emerging conceptions, identities, and practices. Journal of School Leadership, 11 (1), 624.

Guba, E. G., \& Lincoln, Y. S. (1994). Competing paradigms in qualitative research. In N.K. Denzin, \& Y.S. Lincoln (Eds.), Handbook of qualitative research (pp. 163-194). Thousand Oaks, CA: Sage.

Howe, A. C., \& Stubbs, H. S. (2003). From science teacher to teacher leader: Leadership development as meaning making in a community of practice. Science Education, 87(2), 281-297.

Hunzicker, J. (2012). Professional development and job-embedded collaboration: How teachers learn to exercise leadership. Professional Development in Education, 38(2), 267-289.

Jacobson, S (2011). Leadership effects on student achievement and sustained school success. International Journal of Educatinal Management, 25(1), 33-44.

Katzenmeyer, M., \& Moller, G. (2009). Awakening the sleeping giant: Helping teachers develop as leaders. Thousand Oaks, CA: Corwin Press.

Kenreich, T. W. (2002). Professional development becomes political: Geography's corps of teacher leaders. Theory and Research in Social Education, 30(3), 381-400.

Komives, S. R., Owen, J. E., Longerbeam, S. D., Mainella, F. C., \& Osteen, L. (2005). Developing a leadership identity: A grounded theory. Journal of College Student Development, 46(6), 593 -611. 
Krause, N. (2004). Stressors arising in highly valued roles, meaning in life, and the physical health status of older adults. The Journals of Gerontology Series B: Psychological Sciences and Social Sciences, 59(5), 287-297.

Larkin, D. B., Seyforth, S. C., \& Lasky, H. J. (2009). Implementing and sustaining science curriculum reform: A study of leadership practices among teachers within a high school science department. Journal of Research in Science Teaching, 46(7), 813-835.

Leonard, J., Petta, K., \& Porter, C. (2012). A fresh look at graduate programs in teacher leadership in the United States. Professional Development in Education, 38(2), 189-204.

Lewthwaite, B. (2006). Constraints and contributors to becoming a science teacher- leader. Science Education, 90(2), 331-347.

Lieberman, A. (1988). Teachers and principals: Turf, tension, and new tasks. The Phi Delta Kappan, 69(9), 648-653.

Lieberman, A., \& Miller, L. (2007). What research says about teacher leadership. In R. H. Ackerman \& S. V. MacKenzie (Eds.), Uncovering teacher leadership (pp. 37-50). Thousand Oaks, CA: Corwin Press.

Loeb, H., Elfers, A. M., \& Plecki, M. L. (2010). Possibilities and potential for improving instructional leadership: Examining the views of national board teachers. Theory Into Practice, 49(3), 223-232.

Lord, B., Cress, K., \& Miller, B. (2008). Teacher leadership in support of large-scale mathematics and science education reform. In M. Mangin \& S. R. Stoelinga (Eds.), Effective teacher leadership (pp. 55-76). New York: Teachers College Press.

Luehmann, A. L. (2007). Identity development as a lens to science teacher preparation. Science Education, 91(5), 822-839.

Luft, J.A., \& hEWSON, P.W. (2014). Research on teacher professional development programs in science. In S.K. Abell \& N, Lederman (Eds.), Handbook of Research in Science Education $2^{\text {nd }}$ edition (pp. 889-909). New York: Routledge.

Luft, J. A., Dubois, S. L., Kauffman, J., \& Plank, L. (2016). Science Teacher Leadership: Learning from a Three-year Leadership Program. Science Educator Summer 25(1),1-9.

Margolis, J., \& Deuel, A. (2009). Teacher leaders in action: Motivation, morality, and money. Leadership and Policy in Schools, 8(3), 264-286. 
Martinez, M. C. (2004). Teachers working together for school success. Thousand Oaks, CA: Corwin Press.

Mentzer, G. A., Czerniak, C. M., \& Struble, J. L. (2014). Utilizing program theory and contribution analysis to evaluate the development of science teacher leaders. Studies in Educational Evaluation, 42, 100-108.

National Science Foundation (2010). Math and Science Partnership Program Solicitation. Retrived on 21 January, 2016 from: http://www.nsf.gov/pubs/2010/nsf10556/nsf10556.htm

Patton, M. Q. (2001). Qualitative evaluation and research methods (2nd ed.). Newbury Park, CA: Sage.

Pellicer, L. O., \& Anderson, L. W. (2001). Teacher leadership: A promising paradigm for improving instruction in science and mathematics. In C.R. Nesbit, J.D. Wallace, D.K. Pugalee, A.C. Miller, \& W.J. DiBiase (Eds.), Developing teacher leaders: Professional development in science and mathematics (pp. 1-16). Columbus, OH: ERIC Clearinghouse for Science, Mathematics and Environmental Education.

Pounder, D. G., Ogawa, R. T., \& Adams, E. (1995). Leadership as an organization-wide phenomena: Its impact on school performance. Educational Administration Quarterly, 31(4), 564-588.

Renn, K. A., \& Bilodeau, B. L. (2005). Leadership identity development among lesbian, gay, bisexual, and transgender student leaders. Naspa Journal, 42(3), 342-367.

Ross, D., Adams, A., Bondy, E., Dana, N., Dodman, S., \& Swain, C. (2011). Preparing teacher leaders: Perceptions of the impact of a cohort-based, job embedded, blended teacher leadership program. Teaching \& Teacher Education, 27(8), 1213-1222.

Sharon, F. R., \& Highsmith, M. C. (1986). The Myth of the 'Great Principal': Questions of School management and instructional leadership. The Phi Delta Kappan, 68(4), 300-304.

Stogdill, R. M. (1974). Handbook of Leadership. London: The Free Press.

Taylor, M., Goeke, J., Klein, E., Onore, C., \& Geist, K. (2011). Changing leadership: Teachers lead the way for schools that learn. Teaching and Teacher Education, 27(5), 920-929.

Taylor, M., Yates, A., Meyer, L. H., \& Kinsella, P. (2011). Teacher professional leadership in support of teacher professional development.Teaching and Teacher Education, 27(1), 8594. 
Wallace, J. D., Nesbit, C. R., \& Miller, A. C. S. (1999). Six leadership models for professional development in science and mathematics. Journal of Science Teacher Education, 10(4), 247-268.

Wasley, P. A. (1991). Teachers who lead: The rhetoric of reform and the realities of practice. New York: Teachers college press.

Weiner, J. M. (2011). Finding common ground: Teacher leaders and principals speak out about teacher leadership. Journal of School Leadership, 21(1), 7-41.

Yin, R. K. (2003). Case study research: Design and methods (Vol. 5). Newbury Park, CA: Sage Publication.

York-Barr, J., \& Duke, K. (2004). What do we know about teacher leadership? Findings from two decades of scholarship. Review of Educational Research, 74(3), 255-316.

Yost, D. S., Vogel, R., \& Liang, L. L. (2009). Embedded teacher leadership: support for a sitebased model of professional development. International Journal of Leadership in Education, 12(4), 409-433.

Yow, J. A., \& Lotter, C. (2014). Teacher learning in a mathematics and science inquiry professional development program: First steps in emergent teacher leadership. Professional Development in Education, 40 (1), 1-27. 


\section{Captions \& Titles}

\section{$\underline{\text { Figure Captions }}$}

Figure 1.Brandon's disconnected teacher leadership components

Figure 2.Brandon's teacher leadership development

Figure 3.Elisa's disconnected teacher leadership components

Figure 4. Elisa's teacher leadership development

Figure 5. Martin's disconnected teacher leadership development components

Figure 6. Martin's teacher leadership development

Figure 7. Teacher Leadership development process

\section{$\underline{\text { Table Titles }}$}

Table 1

Seven dimensions of teacher leadership practice

Table 2

Data Sources.

Table3

Example of grouping similar codes

Table4

Summary table of Elisa's comments to peers' blog posts

Table5

Brandon's leadership practices

Table6

Elisa's leadership practices

Table7

Martin's leadership practices 